\title{
時効硬化 $\mathrm{Al}$ 合金切欠材の疲労強度に及ぼす湿度の影響†
}

$\begin{aligned} \text { 皮籠石 紀 雄* } & \text { 金 丸 智 紀** } \\ & \text { 仮 屋 孝 二 } \text { ～}^{* *} \text { 大 園 義 久**** }\end{aligned}$

Effect of Humidity on Fatigue Strength of Notched Age-Hardened Al Alloy

by

\author{
Norio KawagoIShI ${ }^{*}$,Tomonori Kanemaru ${ }^{* *}$, Koji KarIYA ${ }^{* * *}$ and Yoshihisa Ohzono ${ }^{* * * *}$
}

In order to investigate the effect of humidity on fatigue strength of an extruded and age-hardened Al alloy 7075-T6, rotating bending fatigue tests were carried out using plain specimens and circumferential notched ones with notch radii of $1.0,0.1$ and $0.05 \mathrm{~mm}$ in environments of relative humidity $25 \%$ and $85 \%$. Fatigue strength was decreased by high humidity, except for notched specimen with notch radius of $0.1 \mathrm{~mm}$. Fatigue limit for notched specimen with notch radius of $0.05 \mathrm{~mm}$ was very high in low humidity. Notch sensitivity for crack initiation was low and the one for crack propagation was reversely high in high humidity. Branch points were $0.05-0.1 \mathrm{~mm}$ in low humidity and about $0.3 \mathrm{~mm}$ in high one, respectively. Crack in sharply notched specimen tended to propagate in shear mode in low humidity with decreases in stress level, though all of crack propagations were in tensile mode in high humidity. This was a main reason for high fatigue limit in notched specimen with notch radius of $0.05 \mathrm{~mm}$ in low humidity.

Key words : Fatigue, 7075-T6, Rotating bending, Notch sensitivity, Humidity, Fatigue limit, Crack initiation, Crack propagation

\section{1 緒言}

高強度 $\mathrm{Al}$ 合金は，比強度が高く耐食性やリサイクル の点で優れているため, 環境負荷低減の観点から機器用 材料としての使用が多い。しかしながら, 疲労特性上の 問題，例えば疲労限度比は低く，切欠きに敏感であるな どの使用上注意すべき点も多い．著者の一人は，3種の 時効硬化 Al 合金 7075-T6，2017-T4 および 6061-T6 を用 いて大気中で回転曲げ疲労試験を行い，切欠き材の疲労 特性を検討した.1)その結果，切欠き感度は，7075-T6が 最も高く次いで 2017-T4，6061-T6の順に低くなり，静強 度が高いほど切欠きに敏感であること, その主な理由を き裂伝ぱ形態に起因した破面粗さ誘起き裂閉口効果の相 違から説明した。ところで時効硬化 $\mathrm{Al}$ 合金のような高強 度化された材料の場合, 通常マイルドとされる大気中で あっても湿度により疲労強度は大きく影響されることが ある.2) 6)すなわち湿度が高くなると, き裂発生過程では 腐食ピットの発生が，そして伝ぱ過程ではぜい性割れが 生じることがあり，それらによって，両過程は加速され， 結果として疲労強度は低下する.5)そして, 湿度の影響は $\mathrm{Cu}$ を含む 7075- T6 の場合特に顕著である.5)

そこで本研究では，Al- $\mathrm{Zn}-\mathrm{Mg}-\mathrm{Cu}$ 系の時効硬化 $\mathrm{Al}$ 合金 7075-T6 を用いて, 相対湿度 25\% と 85\% の環境下で回転 曲げ疲労試験を行い，切欠き材の疲労強度について検討 した。

\section{2 材料, 試験片および実験方法}

用いた材料は，市販の時効硬化 $\mathrm{Al}$ 合金 7075-T6（直径 $22 \mathrm{~mm}$ の丸棒）である。その化学成分を Table 1 に示 す.素材は, T6の条件で時効処理された状態で納入され たものである.

Fig. 1 に組織写真を示す。丸棒の横断面で観察した平 均結晶粒径は約 $10 \mu \mathrm{m}$ である。

Fig. 2 に，EBSD（電子線後方散乱）法により調べた 結晶方位を示す。強度の押出加工を反映して $<111>$ 方 向を主方位とした顕著な集合組織を呈している。

Table 2 に機械的性質を示す.

Fig. 3 に試験片の形状，寸法を示す。ここで用いた平 滑材は疲労被害の観察を容易にするため, 完全な平滑試 験片（応力集中係数 $K_{t}=1$ ）ではなく, 鈍く浅い円周切 欠き材 $\left(K_{t}=1.04\right)$ を用いているが, 以下ではこの試験片 を平滑材と呼ぶ。試験片表面は, 平滑材の場合, エメリー ペーパーによる研磨の後, 電解研磨で約 $20 \mu \mathrm{m}$ 除去し, 切欠き材の場合，切欠き底をダイアモンドペーストで研 磨してから約 $10 \mu \mathrm{m}$ 電解研磨し, 最終仕上げとした. 平滑 材におけるき裂の観察はレプリカ法で行い，切欠き材に おけるき裂は切欠き底を直接光学顕微鏡で観察した。用

Table 1 Chemical composition. (wt.\%)

\begin{tabular}{|c|c|c|c|c|c|c|c|c|}
\hline $\mathrm{Si}$ & $\mathrm{Cu}$ & $\mathrm{Fe}$ & $\mathrm{M}$ & $\mathrm{Mg}$ & $\mathrm{Cr}$ & $\mathrm{Zn}$ & $\mathrm{Zr}+\mathrm{Ti}$ & $\mathrm{Ti}$ \\
\hline 0.09 & 1.47 & 0.25 & 0.03 & 2.56 & 0.19 & 5.46 & 0.03 & 0.03 \\
\hline
\end{tabular}

\footnotetext{
$\dagger \quad$ 原稿受理 平成 21 年 1 月 23 日 Received Jun. 23, 2009 C 2009 The Society of Materials Science, Japan

* 正会員 鹿児島大学工学部機械工学科 干890-0065 鹿児島市郡元, Faculty of Eng., Kagoshima Univ., Korimoto, Kagoshima, 890-0065

** 学生会員 鹿児島大学大学院理工学研究科 =890-0065 鹿児島市郡元, Faculty of Eng., Kagoshima Univ., Korimoto, Kagoshima, 890-0065

*** 正 会 員 第一工業大学機械システム工学科 †899-4395 霧島市国分中央, Daiichi Univ. Coll. of Tech., Kokubu-chuo, Kirishima, 899-4395

**** 鹿児島大学 FSRC 機器分析室 =890-0065 鹿児島市郡元, FSRC, Kagoshima Univ., Korimoto, Kagoshima, 890-0065
} 


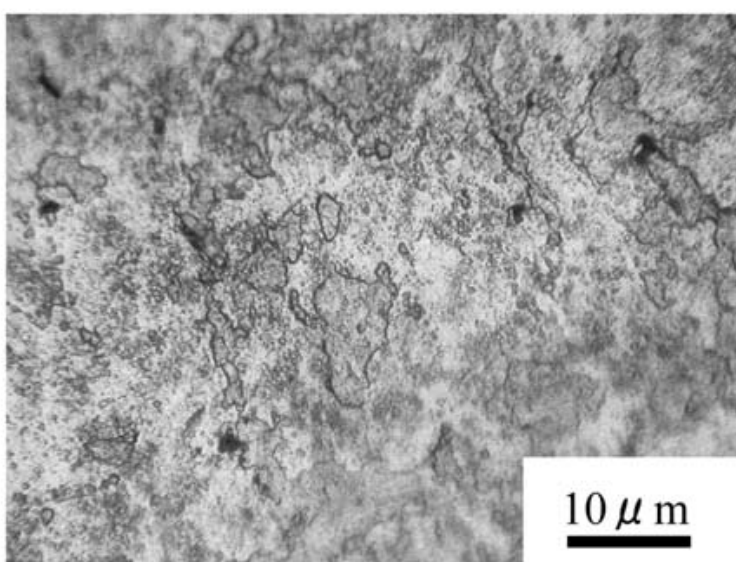

Fig. 1 Microstructure.

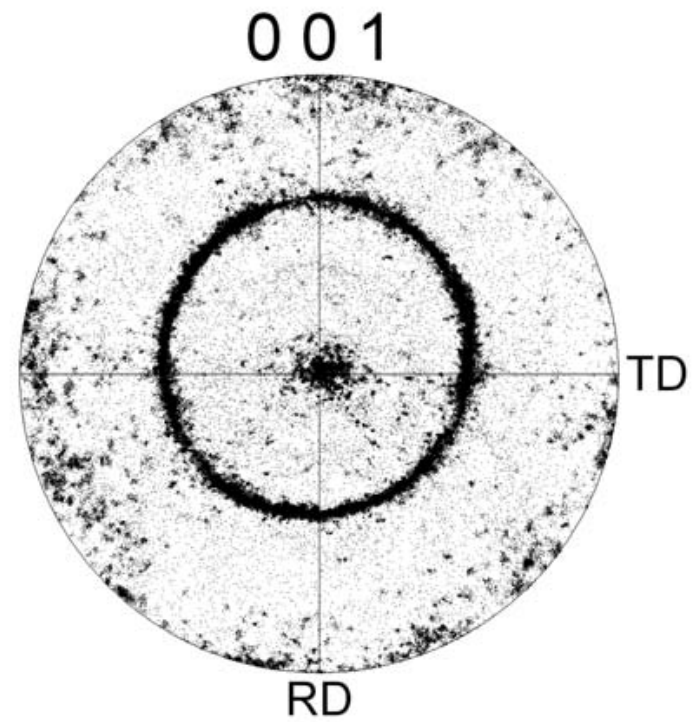

Fig. 2 Pole figure.

Table 2 Mechanical properties.

\begin{tabular}{c|c|c|c|c}
\hline$\sigma_{0.2}(\mathrm{MPa})$ & $\sigma_{\mathrm{B}}(\mathrm{MPa})$ & $\sigma_{\mathrm{T}}(\mathrm{MPa})$ & $\Psi(\%)$ & $H v$ \\
\hline 630 & 691 & 764 & 9.5 & 182 \\
\hline
\end{tabular}

いた試験機は小野式回転曲げ度労試験機（容量 $15 \mathrm{~N} \cdot \mathrm{m}$, 繰返し速度約 $50 \mathrm{~Hz}$ ) である。試験環境は, 相対湿度 $25 \%$ および $85 \%$ であり, 湿度の制御は, 試験機全体をビ ニールでカバーしたキャビンで覆い, 加湿器と除湿器を 併用することで行った。このときの湿度は設定值 $\pm 5 \%$ で あった。

\section{3 実験結果および考察}

\section{$3 \cdot 1$ 切欠感度に及ぼす湿度の影響}

Fig. 4 に, 両湿度条件下での平滑材と切欠き材の S-N 曲線をまとめて示す，以下では $10^{7}$ 回の応力繰返しで破 断しない限界を疲労限度と定義する。疲労強度は切欠き が鋭いほど低下するが，低湿度の $\rho=0.05 \mathrm{~mm}$ の場合応 力集中係数 $K_{t}=3.54$ と高いにも係わらず平滑材と同程 度もしくは高い疲労強度である。年のため, 本切欠き材 では破断が切欠き部でなく平滑部から生じることもあっ た (図中矢印)。さらに, 一般に高湿度になると疲労強度 は低下し，それは低応力ほど顕著となる。本結果におけ

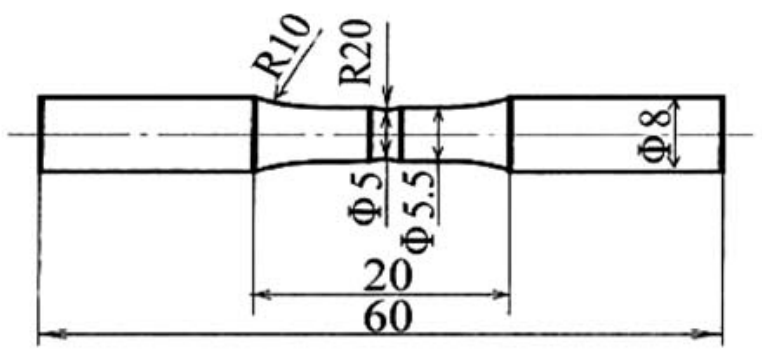

(a) Plain specimen

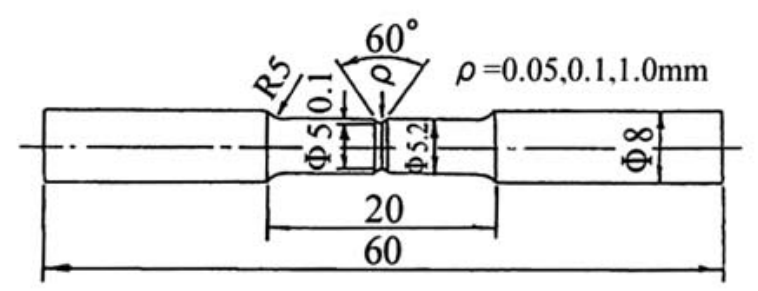

(b) Notched specimen

Fig. 3 Shape and dimensions of specimens.

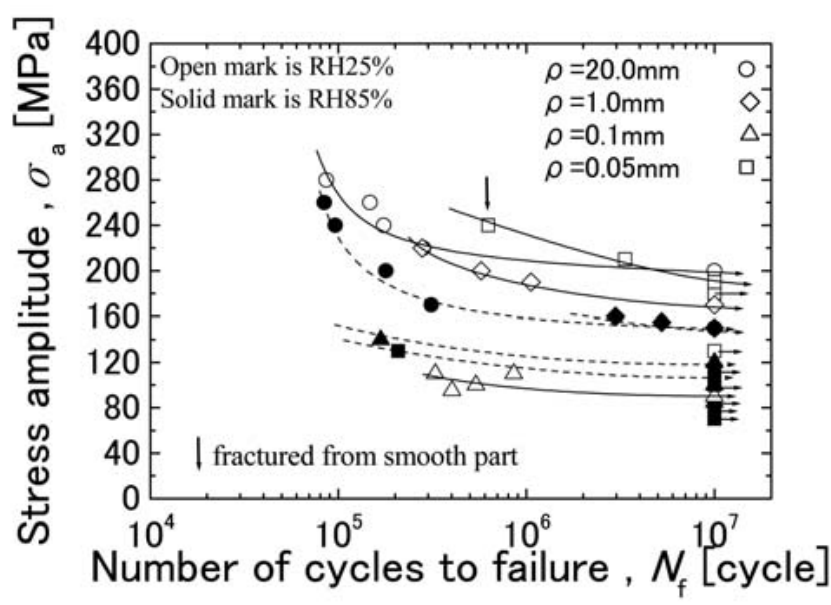

Fig. 4 S- $N$ curves.

る疲労限度近傍での強度は, 平滑材の場合低下するが， 切欠き材の場合, $0.05 \mathrm{~mm}$ では低下するのに対し $\rho=$ $0.1 \mathrm{~mm}$ では逆に増加し, 湿度の影響は複雑である。

Fig. 5 に, 鋭い切欠き材 (低湿度の場合, $\rho=0.05 \mathrm{~mm}$ のみ, 高湿度の場合 $\rho=0.1$ と $0.05 \mathrm{~mm}$ ）の疲労限度で 観察された停留き裂の例を示す．な打他の切欠き半径で は停留き裂は観察されなかった。低湿度の場合，切欠き 底を一本のき裂が伝ぱするのに対し，高湿度の場合，複 数のき裂が発生, 伝ぱする傾向がみられる.

Table 3 に疲労限度をまとめる。ここで, $\sigma_{w 0}$ は平滑 材の疲労限度（前述のように, ここでは R 20 の円周切欠 き材で求めているので応力集中のない平滑材の疲労限度 $\sigma_{w 0}$ は応力集中係数 1.04 を乗じて求めた)， $\sigma_{w 1}$ および $\sigma_{w 2}$ はそれ学れ切欠き材に打けるき裂の発生限界および 伝ぱ限界に対する疲労限度である。

Fig. 6 に, 疲労限度と応力集中係数 $K_{t}$ の関係を示す. 図には著者らの先の結果（静強度および結晶粒径は今回 とほぼ同じであるが，試験環境は大気中であり，湿度は 測定していない ${ }^{1)} も$ 示してある。前述のように, 高湿度 により平滑材の疲労限度はかなり低下するが，切欠き材 


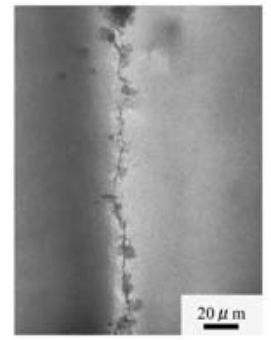

(a) RH25\% ( $\left.\rho=0.05 \mathrm{~mm}, \sigma_{\mathrm{w} 2}=190 \mathrm{MPa}\right)$

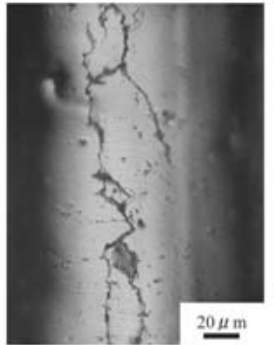

(b-1) $\rho=0.05 \mathrm{~mm}$ $\left(\sigma_{\mathrm{w} 2}=150 \mathrm{MPa}\right)$

(b) $\mathrm{RH} 85 \%$

Fig. 5 Non-propagating cracks in notched specimens.

Table 3 Fatigue limits $\sigma_{w 0}, \sigma_{w 1}$ and $\sigma_{w 2}$.

\begin{tabular}{|c|c|c|c|c|c|}
\hline \multirow{2}{*}{$\mathrm{RH}(\%)$} & $\begin{array}{c}\rho \\
(\mathrm{mm})\end{array}$ & $K_{t}$ & $\begin{array}{c}\sigma_{w 0} \\
(\mathrm{MPa})\end{array}$ & $\begin{array}{c}\sigma_{w 1} \\
(\mathrm{MPa})\end{array}$ & $\begin{array}{c}\sigma_{w 2} \\
(\mathrm{MPa})\end{array}$ \\
\hline \multirow{4}{*}{25} & 20 & 1.04 & $218^{*}$ & 210 & - \\
\cline { 2 - 6 } & 1 & 1.41 & - & 185 & - \\
\cline { 2 - 6 } & 0.1 & 2.72 & - & 100 & - \\
\cline { 2 - 6 } & 0.05 & 3.54 & - & 90 & 180 \\
\hline \multirow{4}{*}{85} & 20 & 1.04 & $166^{*}$ & 160 & - \\
\cline { 2 - 6 } & 1 & 1.41 & - & 150 & - \\
\cline { 2 - 6 } & 0.1 & 2.72 & - & 100 & 130 \\
\cline { 2 - 6 } & 0.05 & 3.54 & - & 80 & 150 \\
\hline
\end{tabular}

$* \sigma_{\mathrm{w} 0}=1.04 \sigma_{\mathrm{w} 1}$

の場合 $\sigma_{w 1}$ ではその低下は小さく, 切欠きが鋭いほど両 環境間の差は減少する。一方, $\sigma_{w 2}$ では $\rho=0.05 \mathrm{~mm}$ で低 湿度の方が高く, $0.1 \mathrm{~mm}$ では逆に高湿度の方が高くなっ ている。ここでとくに特徴的なことは， $\sigma_{w 2}$ は多くの場 合切欠き半径に無関係にほぼ一定であるが, 1), 7) 99)本結 果では両環境ともに右上がりの傾向で一定值を示さず， とくに低湿度の $\rho=0.05 \mathrm{~mm}$ の $\sigma_{w 2}$ が非常に高いことであ る.また $\rho=0.1 \mathrm{~mm}$ の場合高湿度では停留き裂が存在 し， $\sigma_{w 2}$ が認められるのに対し低湿度ではそれがない（図 中低湿度の場合, このことを考慮して $\sigma_{w 2}$ に対し直線を 引いたがデータは一点であるので分岐点の值は厳密ではな い). その結果, 分岐点の切欠き半径は, 低湿度の場合, $\rho_{0}=0.05 \sim 0.1 \mathrm{~mm}$ であるが, 高湿度の場合 $\rho_{0} \fallingdotseq 0.3 \mathrm{~mm}$ と大きい.

Fig. 7 に, 線形切欠力学 ${ }^{10)}$ に基づき疲労限度に打ける 弾性最大応力と切欠き半径の逆数の関係を示す. 切欠感 度は，き裂発生に対し低湿度で多少敏感であるがその差 は小さいのに対し，き裂伝ぱ限界では高湿度の方が敏感 である。

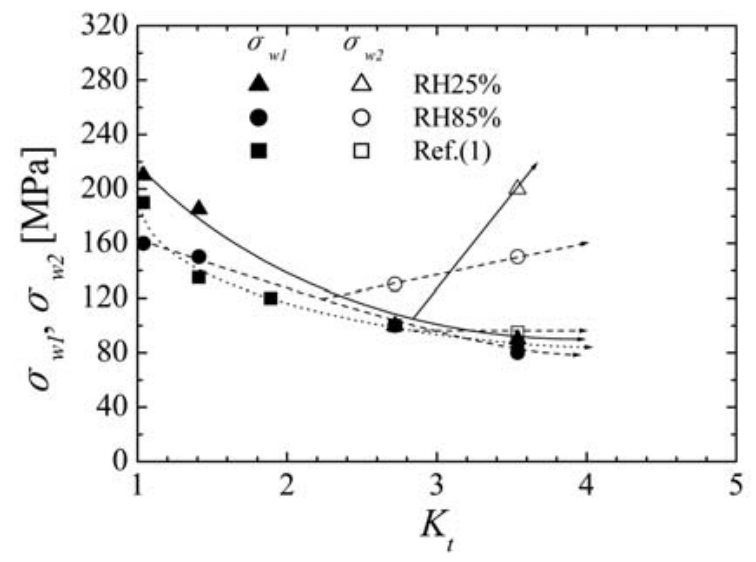

Fig. $6 \sigma_{w 1}$ and $\sigma_{w 2}-K_{t}$.

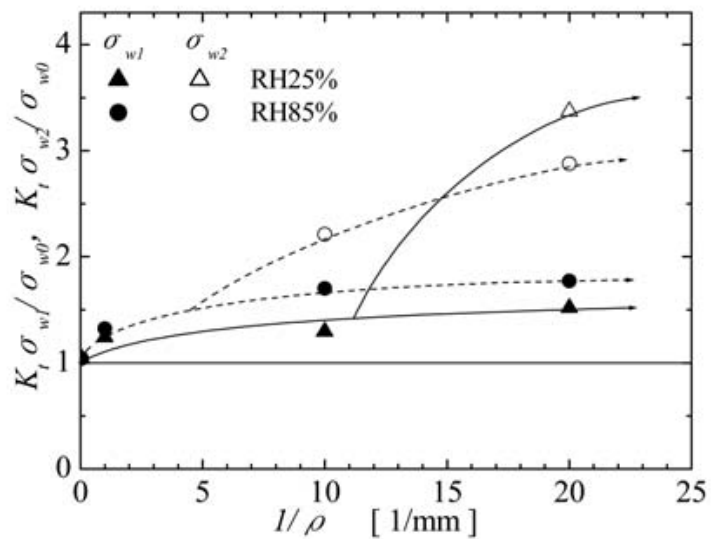

Fig. $7 K_{t} \sigma_{w 1} / \sigma_{w 0}$ and $K_{t} \sigma_{w 2} / \sigma_{w 0}-1 / \rho$.

\section{$3 \cdot 2$ 考察}

以上のように, 切欠感度は $\sigma_{w 1}$ では高湿度の方が低く, $\sigma_{w 2}$ では逆に低湿度の方が低い，また，低湿度に打ける $\sigma_{w 2}$ が非常に高い值となった，以下ではこれらのことに ついてき裂の発生および伝ぱの特徴と破面の観察を通じ て検討する。

Fig. 8 は, 平滑材で観察した両湿度下での疲労被害の 表面に打けるレプリカ写真である。いずれの環境下でも， き裂は電解研磨時に析出物が脱落してできたピットと思 われる微小孔から発生し, せん断形で伝ぱした後引張形 で伝ぱしている。そして環境の影響として，Fig. 5 に示 した停留き裂の場合と同様に，低湿度の場合単独き裂と して直線的に伝ぱする傾向が強いが（Fig. 8 (a)の場合, 2 つのき裂が発生し合体した), 高湿度の場合き裂発生箇 所は複数で, それらは伝ぱ過程で合体しながらジグザグ に伝ぱする。なお, 高湿度の場合疲労過程で腐食ピット が発生, そこからき裂が発生することがある.5. 本研究の 場合でも長寿命になると腐食ピットが観察された。しか し, 破断に導く主き裂の起点はすべて腐食ピット以外で あった。

Fig. 9 は, Fig. 8 に示した場合のき裂伝ぱ曲線である. 同図には，応力繰返し数を破断寿命で基準化した図も示 してある。また図中の卯はき裂が未発生であることを 意味している。高湿度により，き裂の発生と伝ぱのいず れの過程でも加速が生じている. とくに発生過程への影 響が大きい。 

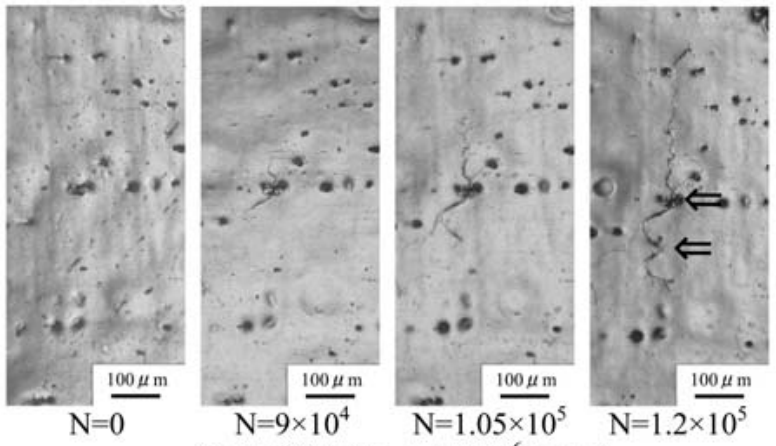

(a) $\mathrm{RH} 25 \%\left(N_{\mathrm{f}}=1.47 \times 10^{6}\right.$ cycles $)$

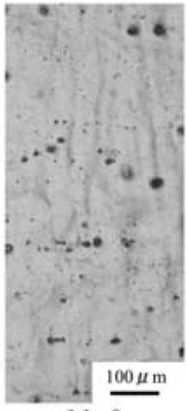

$\mathrm{N}=0$

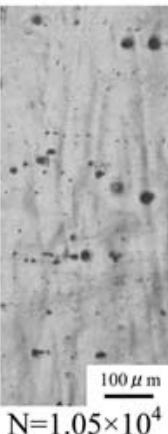

(b) $\mathrm{RH} 85 \%$

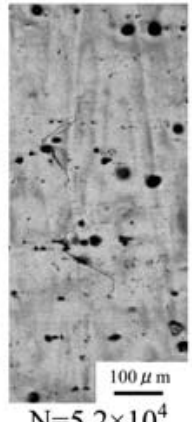

$\mathrm{N}=5.2 \times 10^{4}$

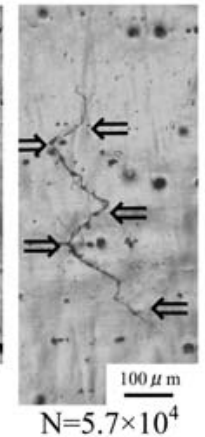

es)
Fig. 8 Change in surface state of specimen due to stress repetitions $\left(\sigma_{a}=260 \mathrm{MPa}, \hookleftarrow\right.$ Axial direction, $\Rightarrow$ Crack initiation site).

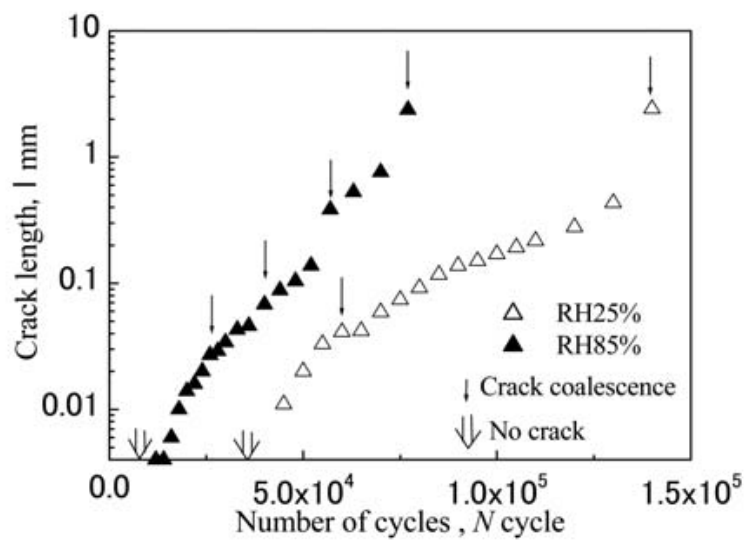

(a) $\ell-N$ curves

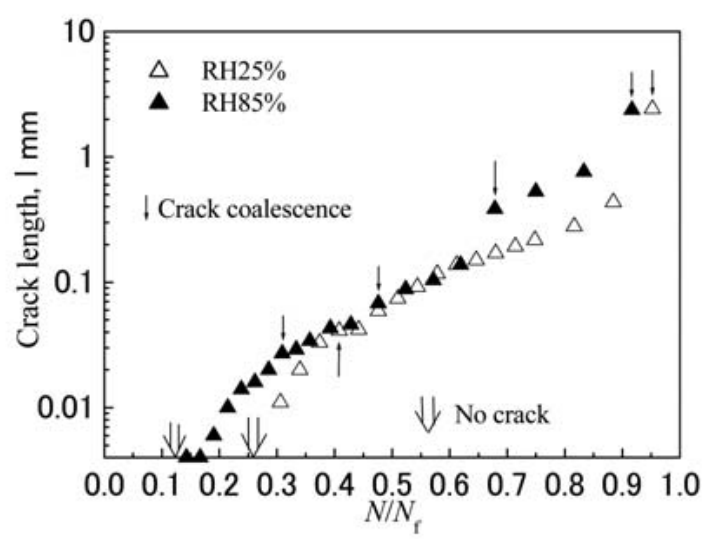

(b) $\ell-N / N_{\mathrm{f}}$ curves

Fig. 9 Crack growth curves $\left(\sigma_{a}=260 \mathrm{MPa}\right)$.
Fig. 10 は，破断した切欠き材の巨視的写真である. 低湿度の場合，切欠きが鋭くなるとせん断形破面となる 傾向がみられる。 $\rho=0.05 \mathrm{~mm}$ の場合破断部の損傷が大 きく，例示していない。これに対し高湿度の場合，切欠 き半径および応力にほぼ無関係に試験片軸に対し直角方 向に破壊している。

Fig. 11 に高湿度下に打ける平滑材の破面写真を示す。 破面はストライエーションで占められ，高湿度の場合で もぜい性破面を確認することはできなかった。

Figs. 8, 9 の結果から, 高湿度による $\sigma_{w 0}$ と $\sigma_{w 1}$ の低 下はき裂発生の加速が主な原因といえるが，き裂発生が 早くなる理由として, 高湿度の場合, 腐食ピットの発生 前の段階としての水分の吸着による表面エネルギーの低 下が考えられる。そして鋭い切欠き材ほど湿度の影響が 小さい理由として確率的な観点から次のように説明でき る。すなわち，腐食により被害を受けることは，平滑材， 切欠き材共に同じであるが，破壊が生じる領域に生じる 腐食被害域は切欠き材の方が，そして鋭い切欠きのほう がせまい。つまり鋭い切欠き材ほど腐食被害の程度は確

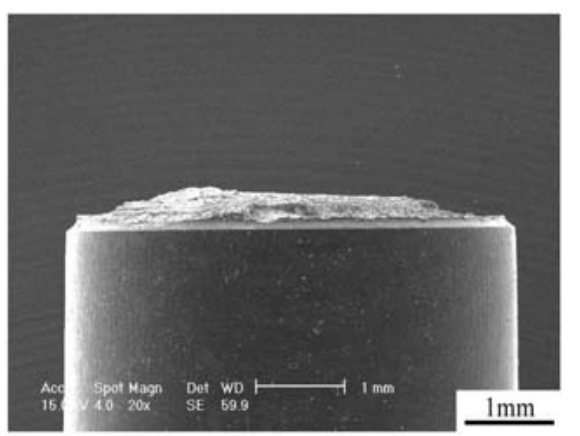

(a) $\mathrm{RH} 25 \%\left(\rho=0.1 \mathrm{~mm}, \sigma_{\mathrm{a}}=110 \mathrm{MPa}, N_{\mathrm{f}}=8.58 \times 10^{5}\right.$ cycles $)$

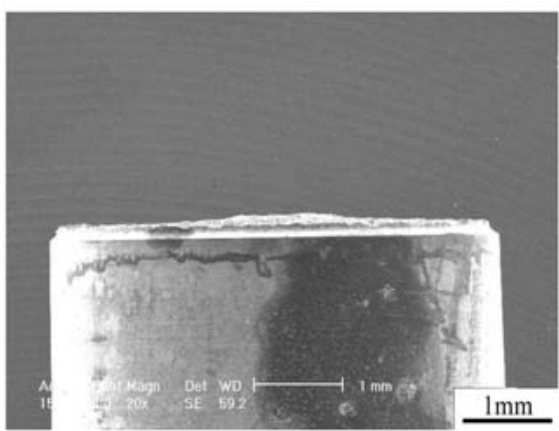

(b) RH $85 \%$ ( $\rho=0.1 \mathrm{~mm}, \sigma_{\mathrm{a}}=140 \mathrm{MPa}, N_{\mathrm{f}}=1.68 \times 10^{5}$ cycles )

Fig. 10 Feature of fractured specimens.

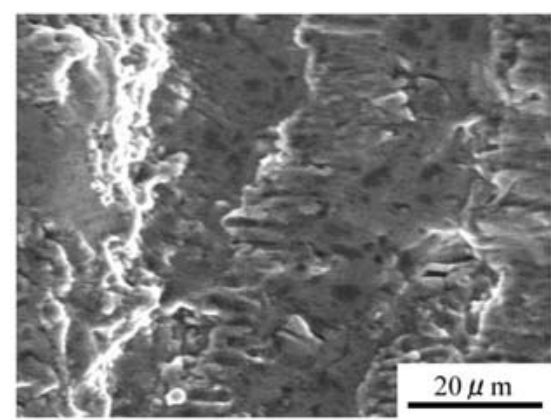

Fig. 11 Fracture surface (Plain specimen). (RH85\%, $\sigma_{a}=260 \mathrm{MPa}, N_{f}=8.4 \times 10^{5}$ cycles) 
率的に低くなる。一方 $\sigma_{w 2}$ の場合, $\rho=0.05 \mathrm{~mm}$ の低湿 度に打いて非常に高く，平滑材と同程度の瘦労強度を示 した。これは，Fig. 10 に示したように，き裂がせん断形 で伝ぱしたため，き裂は存在してもき裂面が曲げ荷重を 負担したためだと考えられる。したがって，例えば軸荷 重を受けるような負荷形式では本結果とは異なることが 推定される。そして，せん断形伝ぱとなった理由として， Fig. 2 に示したように，本材料は $<111>$ 方向の顕著な集 合組織を有していることから，集合組織の関与が考えら れる。このようなせん断形伝ぱは，これまでにも時効硬化 $\mathrm{Al}$ 合金押出し材の水分あるいは酸素の少ない条件 11$), 12)$ や特定の切欠形状と応力下 12) 16)で観察されており，そ の原因として上述した集合組織だけでなく，環境や力学 的要因が指摘されている。一方高湿度においては $\rho=$ $0.1 \mathrm{~mm}$ でもき裂が停留した。これは前述のように低湿度 の場合, き裂の発生と伝ぱのほとんどで単独き裂となる のに対し, 高湿度の場合, 複数のき裂が発生, 伝ぱする. その結果応力軸に対し垂直な平行き裂による応力緩和や ジグザグ伝ぱによるき裂閉口効果によりき裂が停留しや すくなったためであると考えられる.

このように本材料の切欠き材の場合，き裂伝ぱが環境 だけでなく組織や切欠き形状と応力レベルに影響される ためき裂伝ぱ限界である $\sigma_{w 2}$ は複雑に変化する.

\section{4 結}

\section{言}

$\mathrm{Al}-\mathrm{Zn}-\mathrm{Mg}-\mathrm{Cu}$ 系の時効硬化 $\mathrm{Al}$ 合金 7075-T6 を用いて， $25 \%$ と $85 \%$ の湿度環境下で回転曲げ疲労試験を行い，切 欠感度に及ぼす湿度の影響について検討した。得られた 主な結論は以下の通りである。

(1) 高湿度になると疲労限度近傍での強度は, 平滑材 の場合低下するが, 切欠き材の場合 $\rho=0.1 \mathrm{~mm}$ では増 加し， $0.05 \mathrm{~mm}$ では低下した。

(2) 切欠き材の疲労限度では, 低湿度の場合 $\rho=0.05$ $\mathrm{mm}$ で, 高湿度の場合 $\rho=0.05 \mathrm{~mm}$ と $\rho=0.1 \mathrm{~mm}$ で停留 き裂が生じた。

(3) $\sigma_{w 2}$ はいずれの環境下でも右上がりとなり，とく に低湿度の場合 $\rho=0.05 \mathrm{~mm}$ の切欠き材の疲労限度は非 常に高い.

（4）分岐点の切欠き半径は，低湿度の場合 $\rho_{0}=0.05-$ $0.1 \mathrm{~mm}$ ，高湿度の場合 $\rho_{0} \fallingdotseq 0.3 \mathrm{~mm}$ であった。

（5）切欠感度は，き裂発生に対し低湿度で多少敏感 であるのに対し，き裂伝ぱ限界では高湿度の方が敏感で ある。

（6）低湿度の場合，切欠きが鋭くなると，また応力が 低くなるとせん断形破面となった.

本研究において，EBSDの使用と解析で協力いただい た本学の中村祐三准教授と, 卒業研究の一部として実験 いただいた当時鹿児島大学工学部機械工学科学生古本真 一郎君に謝意を表します。

\section{参 考 文 献}

1) H. Nisitani and N. Kawagoishi, "Comparison of notch sensitivities in three aged-hardened aluminum alloys", Transactions of Japan Society of Mechanical Engineers, A, Vol.51, No.462, pp.530-533 (1985).

2) K. Endo, K. Komai, T. Fujimoto and Y. Matsuda, "Fatigue crack growth under stress corrosion of a high strength steel”,
Transactions of Japan Society of Mechanical Engineers, A, Vol45, No.398, pp.1152-1159 (1979).

3 ) K. Asami and H. Emura, "The influence of moisture in air on fatigue crack propagation characteristics of high-strength steels”, Journal of the Society of Materials and Science, Japan, Vol.39, pp.425-431 (1990).

4) T. Broom and A. Nicholson, "Atmospheric corrosion-fatigue of age-hardened aluminum alloys", Journal of the Institute of Metals, Vol.89, pp.183-190 (1961).

5) Haftirman, S. Hattori and T. Okada, "Fatigue strength of aluminum alloys in high humidity environment", Transaction of the Japan Society of Mechanical Engineers, Series A, Vol.62, No.597, pp.1140-1145 (1996).

6 ) K. Ichitani and K. Koyama, "Effect of experimantal humidity on the fatigue properties of 6061 aluminum alloy sheets", Proceedings of Japan Institute of Light Metals, pp.125-126 (2006).

7) H. Nisitani and S. Nishida, "The change of surface states and the incipient fatigue cracks in electro-polished low carbon steel (Plain and notched specimens) subjected to rotating bending stress", Transactions of Japan Society of Mechanical Engineers, Vol.35, No.280, pp.2310-2315 (1969).

$8)$ H. Nisitani, H. Noguchi, H. Uchibori and H. Nakae, "A Examination of notch effects in fatigue of carbon steel by linear notch mechanics", Transaction of the Japan Society of Mechanical Engineers, Series A, Vol.54, No.503, pp.12931297 (1988).

$9)$ N. Kawagoishi, Q. Chen, H. Nisitani, M. Goto and E. Kondo, "Notch sensitivities in fatigue of nickel-base superalloy at elevated temperatures", Transaction of the Japan Society of Mechanical Engineers, Series A, Vol.64, No.627, pp.2869-2875 (1998).

10) H. Nisitani, "Measure of stress field in a notch corresponding to stress intensity factor in a crack", Transaction of the Japan Society of Mechanical Engineers, Series A, Vol.48, No.447, pp.1353-1359 (1983).

11) T. Okada, Y. Iwai and S. Sayama, "Cup and cone fracture and environmental fatigue strength of high tensile-strength aluminum alloys", Journal of the Society of Materials and Science, Japan, Vol.31, No.343, pp.383-389 (1982).

12) N. Kawagoishi and H. Nisitani, "Relation between fatigue strength and crack morphology of age-hardened $\mathrm{Al}$ alloy in an oil environment", Transaction of the Japan Society of Mechanical Engineers, Series A, Vol.55, No.512, pp.703-709 (1989).

13) J. M. Finney and J. Y. Mann, "Abnormally high fatigue strength aluminum alloy extruded bar”, Nature, Vol.182, pp.1366-1367 (1958)

14) R. Koterasawa and D. Shimo, "An electron fractographic observation of the cup and cone fatigue fracture”, Journal of the Society of Materials and Science, Vol.27, No.295, pp.327-328 (1978).

15) N. Kawagoishi, M. Oki, M. Goto, Q. Chen and Q.Y. Wang, "Crack growth behavior of $\mathrm{Al}$ alloy 7075-T6 under ultrasonic fatigue”, Transaction of the Japan Society of Mechanical Engineers, Series A, Vol.72, No.721, pp.1356-1363 (2006). 